\title{
The indirect route of securing interest of consumers and competitors under the EU competition law
}

La ruta indirecta para asegurar los intereses de los consumidores y competidores bajo el derecho de la competencia de la Unión Europea

Autores: Krusha Bhatt

DOI: https://doi.org/10.25058/1794600X.1788

\footnotetext{
Ś MISIÓN JURÍDICA A
} 


\title{
THE INDIRECT ROUTE OF SECURING INTEREST OF CONSUMERS AND COMPETITORS UNDER THE EU COMPETITION LAW*
}

\author{
La ruta indirecta para asegurar los intereses de \\ los consumidores y competidores bajo el derecho \\ de la competencia de la Unión Europea
}

A via indireta de garantia do interesse dos consumidores e concorrentes ao abrigo da legislação da concorrência da UE

Krusha Bhatt ${ }^{\mathrm{a}}$ krushabbhatt@yahoo.com

Fecha de recepción: 22 de abril de 2020 Fecha de revisión: 01 de mayo de 2020 Fecha de aceptación: 02 de junio de 2020

DOI: https://doi.org/10.25058/1794600X.1788

Para citar este artículo:

Bhatt, K. (2020). The indirect route of securing interest of consumers and competitors under the EU competition law. Revista Misión Juridica, 13(20), 88- 96.

\section{ABSTRACT}

The theme of the present article is to deliver the notion that in order to enforce competition rules which, are aimed at maintaining a balance between profitability of the competitors and welfare of the consumers, the crucial aspect in attainting it is a healthy competitive market. Therefore, an attempt is made to analyses the role and practice of the European Courts and the Commission in protecting the structure of the competitive market as a means to secure the interests of the consumers and competitors. To convey the notion of the paper, sustenance from one of the imperative decisions

* Artículo de reflexion.

a. Assistant Lecturer, Jindal Global Law School, LL.M International Commercial and Competition Law, University of East Anglia, $U K$. 
given by the European Court of Justice purporting the predominant idea has been taken from the case of GlaxoSmithKline $v$ Commission $^{1}$ and other relevant cases from the locales of Article 101 coupled with Article 102 of the Treaty on the Functioning of the European Union. The idea is to critically discuss the rationale of the decision delivered by the hierarchy of courts, the object-effect dichotomy under Article 101(1) for apprehending anti- competitive conduct, and to reflect upon the Commission guidelines.

\section{KEY WORDS}

EU Competition Law; Consumer Welfare; Competitors; Market Structure; Object-Effect Dichotomy.

\section{RESUMEN}

El tema de este artículo es dar una noción, para poder fortalecer las reglas de competitividad que apuntan a mantener un balance entre la rentabilidad de los competidores y el bienestar de los consumidores, cuyo aspecto crucial es conseguir un mercado competitivo y sano. Entonces, se realiza un intento por analizar el rol y la práctica de las Cortes Europeas y la Comisión al proteger la estructura de un mercado competitivo como medio para asegurar los intereses de los consumidores y competidores. Para expresar el concepto de esta investigación, se sustenta en una de las decisiones imperativas tomadas por la Corte Europea de Justicia que, avalando la idea predominante, ha sido tomada del caso de GlaxoSmithKline contra la Comisión y otros casos relevantes de los locales del Artículo 101 junto con el Artículo 102 del Tratado del Funcionamiento de la Unión Europea. La idea es discutir de manera crítica el fundamento de la decisión dictada por la jerarquía de tribunales, la dicotomía objeto-efecto bajo el Artículo 101(1) por aprehender conductas anticompetitivas $\mathrm{y}$, además, reflexionar sobre las directrices de la Comisión.

\section{PALABRAS CLAVES}

Derecho de la Competencia de la Unión Europea, bienestar del consumidor, competidores, estructura del mercado, dicotomía objeto-efecto.

\footnotetext{
1. Case C-501/06 P GlaxoSmithKline $v$ Commission ECLI:EU:C:2009:610.
}

\section{RESUMO}

0 tema do presente artigo é transmitir a noção de que para fazer cumprir as regras de concorrência que, visam manter o equilíbrio entre a rentabilidade dos concorrentes e o bem-estar dos consumidores, o aspecto crucial para a sua concretização é um mercado competitivo saudável. Por conseguinte, procura-se analisar o papel e a prática dos Tribunais Europeus e da Comissão na proteção da estrutura do mercado competitivo como meio de salvaguardar os interesses dos consumidores e concorrentes. Para transmitir a noção do documento, o fundamento é uma das decisões imperativas proferidas pelo Tribunal de Justiça das Comunidades Europeias, alegando a ideia predominante, foi tirada do processo GlaxoSmithKline / Comissão e outros casos relevantes das localidades do artigo 101. juntamente com o artigo 102. ${ }^{\circ}$ do Tratado sobre o Funcionamento da União Europeia. A ideia é discutir criticamente a razão de ser da decisão proferida pela hierarquia dos tribunais, a dicotomia objeto-efeito nos termos do artigo 101. ${ }^{\circ}$, n.. 1, para a apreensão de comportamentos anticoncorrenciais, e refletir sobre as orientações da Comissão

\section{PALAVRAS-CHAVES}

Direito da Concorrência da UE; Bem-estar do consumidor; Concorrentes; Estrutura de mercado; Dicotomia objeto-efeito.

\section{INTRODUCCIÓN}

"As a general proposition Competition Law consists of rules that are intended to protect the process of competition in order to maximize consumer welfare." ${ }^{2}$ Consumer Welfare has always been at the heart of EU Commission and the Commission has time and again also emphasised the importance of consumer welfare which can be indicated from the plain readings of Article $101(3)^{3}$ of the Treaty on Functioning

2. Richard Whish and David Bailey, Competition Law, 8th Ed. (Oxford University Press, 2015), p. 1.

3. The provisions of paragraph 1 may, however, be declared inapplicable in the case of:

- any agreement or category of agreements between undertakings, - any decision or category of decisions by associations of undertakings, - any concerted practice or category of concerted practices, which contributes to improving the production or distribution of goods or to promoting technical or economic progress, while allowing consumers a fair share of the resulting benefit, and which does not:

(a) impose on the undertakings concerned restrictions which are not indispensable to the attainment of these objectives; 
of the European Union ('TFEU') and Article 2(1) (b) ${ }^{4}$ of the Merger Control Regulation. ${ }^{5}$ In the recent time a lot of importance has been given to consumer welfare whilst examining competition policy or interpreting competition law. However, "EU law has recognized from the early days that the consumers can be indirectly harmed by the action that harms the competitive structure of the market ${ }^{6}$, and it continues to do so today." ${ }^{7}$ To seize such harm, the Commission has got the backing under Article 101(1) of the TFEU which prohibits agreements between undertakings and related activities that has the potential to adversely affect competition in the market and it either by 'object' or 'effect' prevents, prohibits or distorts the trade between member states. However, the harm caused can be overlooked under the provisions of Article 101(3) which, provides that the procompetitive effects of such an agreement must outweigh the anti- competitive effects in the internal market.

Let us now go through the rationale that the Commission and other EU Courts applied in GlaxoSmithKline.

\section{APPROACH OF THE EU COURTS IN GLAXOSMITHKLINE:}

\subsection{BRIEF FACTUAL BACKGROUND}

It all started back in March 1998, when GW, a Spanish Company, involved in development,

(b) afford such undertakings the possibility of eliminating competition in respect of a substantial part of the products in question.

4. Council Regulation (EC) No 139/2004 of 20 January 2004 on the control of concentrations between undertakings (the EC Merger Regulation), Article 2(1)(b), 'the market position of the undertakings concerned and their economic and financia power, the alternatives available to suppliers and users, their access to supplies or markets, any legal or other barriers to entry, supply and demand trends for the relevant goods and services, the interests of the intermediate and ultimate consumers, and the development of technical and economic progress provided that it is to consumers' advantage and does not form an obstacle to competition.'

5. Wolf Sauter, ' Coherence in EU Competition Law', Oxford University Press, first ed. 2016.

6. Case 6/72 Europemballage and Continental Can v Commission [1973] ECR 215, paras 20-26.

7. Case C- 501/06 P etc Glaxosmithsline Services Unlimited v Commission [2009] ECR I- 9291, para 63; Case C-8/ 08 TMobile Netherlands BV v Raad van bestuur van de Nederlandse Mededingingsautoriteit [2009] ECR I- 4529, para 38. manufacturing and marketing of the medicines in Spain, notified an agreement to the Spanish Competition Authority titled as 'General Sales Conditions' and the lawfulness of such agreement was disputed by the Spanish authorities and a complaint before the EU Competition Commission was made with respect to violation of Article 101(1) of the treaty. ${ }^{8}$

\subsection{THE CONTESTED PART}

The commission was of the opinion that GlaxoSmithKline, one of the world's biggest producers of pharmaceutical products had violated the principles of Article 101(1) by indulging into anti- competitive conduct by charging different prices for the same medicines in Spain. ${ }^{9}$ Clause 4 of Article 1 of the Agreement specified Spanish wholesaler to pay a lower price for the medicines to be sold in the internal market and a higher price for the medicines they trade to other member States. The Commission also opined that the 'dual pricing' system discouraged parallel trade in pharmaceutical sector and the Agreement by its object was anti-competitive in nature. ${ }^{10}$ Commission rejected GW's argument to allow the 'General Sales Condition' under clause (3) of Article 101 to have pro-competitive effect and on the contrary GW argued that Parallel Trade had a negative impact on consumer welfare resulting in negative impact on R\&D because higher price can gain more profits and more investment in $R \& D$.

\subsection{RATIONALE OF THE COURT OF FIRST INSTANCE (CFI)}

The Court, analysed the judgment given by the Commission to examine to what extent the agreement in dispute had the 'object' to restrict parallel trade and violated Competition rules. CFI, although agreed partly with the view of the Commission that the argued agreement indeed had an anti-competitive object, it overturned the Commission's scrutiny that such an agreement was capable of having an anti- competitive effect detrimental to the interest of the final consumer. The decision of the court of first instance showcases that the ultimate goal of competition policy is to promote consumer welfare, which means if the end result of any practice is not resulting on appreciable effect

8. Case C-501/06 P paras 5-10.

9. Glaxo Wellcome (case IV/36.957/F3).

10. Commission Decision 2001/791/EC of 8 May 2001 (OJ L 302 of 17.11.2001) para 189. 
on consumer welfare, it cannot be considered to be anti- competitive under Article 101(1).

\subsection{GAME CHANGER- THE EUROPEAN COURT OF JUSTICE (ECJ)}

The ECJ however, concluded that the court of first instance made an error while asking the GlaxoSmithKline to prove any anti- competitive effect of the Agreement on the final consumer because the wordings of Article 101(1) nowhere suggest that an agreement can be termed as anticompetitive if is detriment to the interest of the final consumer. ${ }^{11}$ The ECJ held that, the aim of Article 101(1) is to not only protect the interest of the consumers or competitors, but like other competition rules, it is important to protect the structure of the market and competition as such. An undertaking cannot continue to do an anticompetitive act on a pre-set notion that there is no loss to end users." 12

The decision delivered by the Commission, reiterates the traditional approach adopted in interference with single economic market concept. Decision of the CFI promotes consumer welfare as an ultimate goal and the decision of ECJ aims to cover a broader perspective of competition policy to weigh a balance between structure of the market as well as interest of consumers by giving both of it equal importance in the role play of Competition Policy.

\section{PRE-POST GLAXOSMITHKLINE OBJECT- EFFECT DICHOTOMY- A NEVER ENDING BATTLE}

It is of utmost importance in the first place to decide, (a) which type of demeanour can be treated as a detriment to competition to be held anti- competitive by object and (b) if it is not necessitous to take a step further and gather economic evidence reflecting the actual effect on the competition or structure of the market. Because for each case, the legal and economic context is different depending on the relevant market structure of the undertaking it operates in. It should also be borne in mind that, competitor doesn't mean only the existing players in the market, it also means the potential players which might be restricted from entering the market

11. Ibid.

12. Case C-501/06 P Glaxosmithkline v Commission para 63. because of such an act in question. Henceforth, all these factors prior to deciding a conduct, need to be taken into account. Let us now first understand how the behaviour of an enterprise quarantines in 'object' or 'effect' box.

Ever since 1966, the principle in Consten and Grunding ${ }^{13}$, one of the first cases to examine anticompetitive agreement by object, has settled that, when an agreement is anti- competitive by its object, the Court doesn't need to consider the harmful effects on the Competition, ${ }^{14}$ when the agreement between German manufacturer to sell radios exclusively through French company was restricting competition by not allowing other players to compete in the market. Later in 2008, Beef Industry ${ }^{15}$ case the distinction between 'restrictive by object' and 'restrictive by effect' was clarified stating, "certain forms of collusion between undertakings can be regarded, by their very nature, as being injurious to the proper functioning of normal competition." 16 This legal test has time again reiterated in many cases and set the benchmark to bring a case underneath for the assessment under Article 101(1). The ECJ in T-Mobile ${ }^{17}$ upheld the test which was recited again in GlaxoSmithKline ${ }^{18}$, Football Association Premier League ${ }^{19}$, Allianz Hungária Biztosító Zrt. ${ }^{20}$ and many more.

Contrary to settled law, reasoning of ECJ in Groupement des Cartes Bancaires ${ }^{21}$ is a crucial from two aspects. First, ECJ held, that the object analysis should be applied restrictively unlike as held in other cases and secondly, it again gives an air to the hot debate on object-effect analysis. Needless to say, the bottom line has always been the same, that agreements which restrict competition by object are anti- competitive irrespective of the fact that such agreements

13. Case- 56/64, ECLI:EU:C1966:41.

14. Ibid, Judgment of 13 July 1966- Joined cases 56 and 58/65, p 342 para 5 .

15. Case C-209/07, ECLI:EU:C:2008:643.

16. Ibid, para 17.

17. Case C-8/08, ECLI:EU:C:2009:343, para 29.

18. Joined Cases C-501/06 P, C-513/06 P, C-515/06 P and C-519/06 P, ECLI:EU:C:2009:610, para 55.

19. Joined Cases C-403/08 and C-429/08, ECLI:EU:C:2011:631, para 135.

20. Case C-32/11, ECLI:EU:C:2013:160, paras 33 and 34.

21. Case C-67/13 P, ECLI:EU:C:2014:2204. 
actually caused any harm. Although, the recent judgment again heats up the confusion as it doesn't say anything different, the restrictive approach mention by ECJ is rather controversial.

In the opinion of $A G, W a h l$, the adaptation of the approach under Article 101(1), while examining anti- competitive object, should be cautious and restrictive because only the hardcore agreements which without the need to consider their effects on the market has the serious potential to distort competition can be held restrictive by object. ${ }^{22}$ The differentiation test of object or effect is not a straightjacket formula, the court needs to consider the object, legal and economic context of each case, the functioning of the market in which the undertaking(s) operate are effective criteria to be considered and if the object restriction is not applicable the court still can go on and at length analyze the potential harmful effects on the structure.

As the author feels, this statement tries to argue that, to put a restriction under object box, it has to be sufficiently detriment to have conceivable diminishing consequence on the market, that it is inessential for the commission to actually weigh the economic effects on the market. Therefore, inconsequential anticompetitive object is not treated as a serious conduct. However, author feels that, the approach adopted in previous cases is more economical as the duty of the commission is also to guard in the interest of not only prevailing competitors but also potential players with whom the interest of consumer is attached.

The legal and economic context considered by the CFI in GlaxoSmithKline with respect to allowing shelter under 101(3) was that, the prices of the medicines sold in member states are set by the concerned public authorities and in that way this particular sector different from other consumer goods was immune from the free play of demand and supply. The anti- competitive object of such an agreement did not establish the possible diminishing effect on consumer surplus because the clause of agreement did not hold the potential to make medicines available at a lower price than as regulated under National Health Service laws in respective member states.

22. Case C-67/13 P, ECLI:EU:C:2014:1958, Opinion of Advocate General Wahl, Paras 53- 59.
However, reminding the settled law the ECJ turned the decision because restricting parallel trade in pharmaceutical sector by its very nature is injurious to the competitive structure of the market.

\section{REALITY CHECK OF EU COMMISSION GUIDELINES}

Article 101(3) is reflective upon the procompetitive effects of the Agreements under 101(1), and as per the Council Regulation (EC) No 1/2003, Article 2, the burden of proof is on the undertaking(s) claiming the defence. Looking at the jurisprudence of the most controversial topic it appears that a broader approach has been adopted by the Courts while examining Article 101(1) as the list postulated under Article 101(1) is illustrative and not exhaustive, yet in the recent time numerous incidents amounting to restriction and concerned practices have been covered by the Commission while assessing actions of the enterprise.

The 'Commission Guideline on Effect of Trade Concept' states that, "Agreements and practices that affect the competitive structure inside the community by eliminating or threatening to eliminate a competitor operating within the community may be subject to the community competition rules." 23 This is exactly, in author's view how an object- effect base analysis should be made, as adopted by the ECJ in GlaxoSmithKline.

The relevant paragraph of the judgment in GlaxoSmithKline, goes in conformity with the statement made by Neelie Kroes, that "to achieve consumer welfare and the goal of efficient allocation of resources in the market it is necessary to protect competition in the market. ${ }^{24 "}$ To further comment on the statement, protection of competition means allowing more players in operational market which is not possible in the presence of entry barriers for new entrants or anti- competitive practices of the major players which affects the existing players in the market. The goal of the competition law is to move from

23. Guidelines on the effect on trade concept contained in Articles 81 and 82 of the Treaty, (2004/C 101/07) Commission Notice, Official Journal of the European Union, C 101/81, para 20.

24. Guidelines on the effect on trade concept contained in Articles 81 and 82 of the Treaty, (2004/C 101/07) Commission Notice, Official Journal of the European Union, C 101/81, para 20. 
monopoly to perfect competition in the market, as the judgments restricts the anti- competitive nature of the agreement which hampers parallel trade with member states by way of dual pricing policy that makes it challenging for the domestic players of Spain to reexport mentioned medicines at a higher rate in directly restricting competition in the market.

Under the 'Guidelines on Horizontal Cooperation Agreements, ${ }^{25}$ the Commission provides that, any exchange of information between competitors should be treated as restriction by object ${ }^{26}$ as held in T-Mobile where a single meeting between five mobile operators wherein they discussed to reduce the commission paid to mobile dealers was restrictive by object as it may lead to remove uncertainties from the market and was a concerned practice under 101(1).

\section{SAFEGUARDING COMPETITION UNDER ARTICLE 102}

Many commentators have criticised Article 102 for being inclined towards protecting competitors and not competition. However, the purpose of Article 102 is to protect competition as consumers will be benefitted from competition. The judicial backing of the previous statements come from the Commission guidelines or judgments of EU courts. In 2005, Neelie Kroes, reflected that, first priority under EU Competition Law is given to competition and not competitors because the ultimate goal is consumer surplus, even if it may result in exclusion of competitors from the market as long as consumer are benefitted and the no distortion on the competitive process in the market. ${ }^{27}$

The analogy under Article 101 and 102 for protecting competition is different, as under 101 coordinated behaviour of undertaking is restricted to allow other competitors to operate in the market, more object based approach whereas approach under 102 is to exclude dominant firms who tend to abuse the market in a way removing competitors, more effect based approach, although the ultimate goal is the same, to

25. Official Journal of European Union, (2011/C 11/01).

26. Ibid, para 74 .

27. SPEECH $/ 05 / 537,23$ September 2005; Lowe 'Innovation and Regulation of Dominant Firms'; 23 September 2008 and Alumnia 'converging paths in unilateral conduct', 3 December 2010. eliminate consumer harm and protect the market from any distortion or prevention of competition.

Commission guidelines in various instances also reiterate upon protecting competition, which can be found in Commission's Guidance on Article 102 Enforcement Priorities. ${ }^{28}$ These statements are not only found in papers but also backed by force of law in cases, Deutsche Telekom v Commission ${ }^{29}$, konkurrensverket $v$ TeliaSonera Sverige ${ }^{30}$ and in Post Denmark ${ }^{31}$, moving a bit further it held that Article 102 protects only 'as-efficient' competitors and not inefficient. ${ }^{32}$ However, forming argument on the basis of Hoffmann-La-Roche ${ }^{33}$ and Michelin $^{34} I$, the ECJ has been consistently put efforts to protect competition and competitors in the market as well, when support from previously mentioned cases was taken in British Airways ${ }^{35}$ case, where BA having only $39.7 \%$ of market share was held abusing its dominant position under Article 102, to protect the competitive structure in the market.

Examining an old case on Article 102, the ECJ in Commercial Solvents $v$ Commission ${ }^{36}$ held that, "the requirement of an effect on trade between Member States would be satisfied where conduct brought about an alteration in structure of competition in the internal market." 37 This conduct is important for two reasons, firstly application of Article 102 is restricted to Dominant firms only, secondly, having a large market share, it is very much obvious that anticompetitive conduct of such undertakings are going to affect the structure of the market.

28. OJ [2009] C 45/7, para 5,6,23.

29. Case C-280/08 P [2010] ECR I-9555, para 177.

30. Case C-52/09 [2011] ECR I-527, paras 31-33, 39-43, 63-73.

31. Case C-209/10 EU:C: 2012:172, paras 21,22,25, and 38.

32. Richard Whish and David Bailey, Competition Law, 8th Ed. (Oxford University Press, 2015), p. 207.

33. Case 85/76, Hoffmann-La Roche v Commission, [1979] ECR 461, para 125 .

34. Case T-203/01, Michelin v. Commission, ECLI:EU:T:2003:250, para 54.

35. Case C-95/04 P, British Airways Plc v. Commission, ECLI:EU:C:2007:166, para 106.

36. Case 6/73 and 7/73 [1974] ECR 223, para 33.

37. The Commission refers to the 'Competitive Structure' test at para 20 of its Guidelines on the effect on trade concept contained in Articles [101] and [102] of the Treaty OJ [2004] C 101/81. 


\section{CONCLUSION}

"The complaint of many commentators was that Article 101(1) was applied too broadly, catching many agreements that were not detrimental to the competition at all." ${ }^{38}$ There is a shift in the recent time where the commission has started taking a narrower approach to regulate the anti-competitiveness of an agreement and also in exempting under clause (3) of the Article. Nevertheless, this doesn't mean that the Courts are being lenient or rigorous, it simply tries to convey that there is no way an undertaking can escape from the corners of competition policy to attain its object whatsoever inconsistent with the permissible conduct to operate in the internal market. It is the duty of the Competition authorities to weigh a balance between protecting consumer welfare and restricting anticompetitive conducts of the competitors, however the duty is not just limited here, it continues in protecting the structure of the market as well, because if there are less number of competitors in the market, the possibility of a few firms getting higher market power increases and which is not per se against the goals of Competition Law though the possibility of distortion of market structure and monopolization increases. Therefore, the authorities must ensure fair play in the market, to move towards perfect competition in the market. To elaborate upon the argument, here is a good example. We all know that drink and drive is prohibited under law and it is in no case justifiable to do so if caught, however the argument that nobody was harmed with such a conduct is no excuse from escaping doing what is not legal. Similarly, if conduct of the undertakings, no matter how trivial it may be, if is going against the principles of the competition rules, shall be there and then be restricted. Even if the criteria to determine the harm on competition is different under Article 101 and 102 but they both try to reach the same destination where there is no distortion of competitive structure in the market and hence no harm to the competitors and consumers.

38. Bright 'EU Competition Policy: Rules, Objectives and Deregulation' (1996) 16 OJLS 535.

\section{BIBLIOGRAPHY}

\section{A. Books, Articles and Journals:}

- Richard Whish and David Bailey, Competition Law, $8^{\text {th }}$ Ed. (Oxford University Press, 2015).

- Wolf Sauter, 'Coherence in EU Competition Law', Oxford University Press, first ed. 2016.

- Guidelines on the effect on trade concept contained in Articles 81 and 82 of the Treaty, (2004/C 101/07) Commission Notice, Official Journal of the European Union, C 101/81.

- Guidelines on Horizontal Cooperation Agreements, Official Journal of European Union, (2011/C 11/01).

- Commission's Guidance on Article 102 Enforcement Priorities, OJ [2009] C 45/7.

- Council Regulation (EEC) No 4064/89 on the control of concentrations between undertakings [1990] OJ L257/13.
- Council Regulation (EC) No 139/2004 of 20 January 2004 on the control of concentrations between undertakings (the EC Merger Regulation), Official Journal L 024, 29/01/2004 P. 0001- 0022.

- Bright EU Competition Policy: Rules, Objectives and Deregulation (1996) 16 OJLS 535.

- Speech/05/512 of 15 September 2005 delivered by Neelie Kroes, a member of European Commission on European Competition Policy - Delivering Better Markets and Better Choices.

- SPEECH/05/537, 23 September 2005; Lowe Innovation and Regulation of Dominant Firms; 23 September 2008 and Alumnia converging paths in unilateral conduct, 3 December 2010. 


\section{B. Cases:}

- Case C-501/06 P, GlaxoSmithKline v Commission, ECLI:EU:C:2009:610.

- Case 6/72, Europemballage and Continental Can v Commission, [1973] ECR 215.

- Case C-8/ 08, T- Mobile Netherlands BV v Raad van bestuur van de Nederlandse Mededingingsautoriteit, [2009] ECR I- 4529.

- Case- 56/64, Consten and Grunding, ECLI:EU:C1966:41.

- Case C-67/13 P, Groupement des Cartes Bancaires, ECLI:EU:C:2014:2204.

- Joined Cases C-403/08 and C-429/08, 631, Football Association Premier League, ECLI:EU:C:2011.

- Case C-32/11, Allianz Hungária Biztosító Zrt, ECLI:EU:C:2013:160.

- Case C-209/07, Beef Industry,
ECLI:EU:C:2008:643.

- Case C-280/08 P, Deutsche Telekom v Commission, [2010] ECR I-9555.

- Case C-52/09, Konkurrensverket v TeliaSonera Sverige, [2011] ECR I-527.

- Case C-209/10, Post Denmark, EU:C: 2012:172.

- Case 85/76, Hoffmann-La Roche v Commission, [1979] ECR 461.

- 13. Case T-203/01, Michelin v. Commission, ECLI:EU:T:2003:250.

- Case C-95/04 P, British Airways Plc v. Commission, ECLI:EU:C:2007:166.

- Case 6/73 and 7/73, Commercial Solvents v Commission, [1974] ECR 223.

- Case COMP/M.2220, General Electric/ Honeywell [2004] OJ L48/1. 